\title{
CDM project approval and evaluation criteria: comparative study of Morocco and South Africa
}

\author{
G. Nhamo \\ Department of Geography and Environmental Studies, \\ University of the Witwatersrand, South Africa
}

\begin{abstract}
Since the coming into force of the Kyoto Protocol (KP) in February 2005, the flexible Clean Development Mechanism (CDM) has gained momentum and much recognition in many developing countries globally. Africa, and specifically Morocco and South Africa are part of this band wagon. This paper critically reviews the CDM approval and evaluation criteria for Morocco and South Africa with the view of determining possible future competition points in attracting CDM foreign direct investment in these countries. The paper also serves as a reference point for other developing countries that have or are contemplating implementing CDM project approval and evaluation criteria. The paper shows significant differences in approval time frames and sustainable development criteria. It takes about 42 days in Morocco for proponents to get responses on their proposed CDM projects compared to 60 days (if initial voluntary screening is excluded) and 90 days (if initial voluntary screening is included) in South Africa. Also sustainable development criteria appears to be more stringent for South Africa compared to that of Morocco. By the time of writing this paper, 60 CDM project proposals had been submitted and were at various approval stages in Morocco compared to 20 in South Africa.
\end{abstract}

Keywords: CDM project approval criteria, Morocco, South Africa.

\section{Introduction}

Apart from the traditional determinants of foreign direct investment (FDI), two of the most recent key determinants for attracting CDM project-related FDI by host countries are the CDM project approval and evaluation criteria. Based on 
this assumption, this paper compares these criteria between two African countries namely: Morocco and South Africa. Already, the global spread of CDM project investment Ellis et al [1] depicts a picture of severe imbalances with Korea accounting for 27\%, India (16\%), Brazil (11\%), China (9\%), other Latin American countries (17\%), other Asian countries (18\%), Africa (5\%), Europe (1\%) and none for the Middle East. Such comparison assists in developing competitive environments for attracting CDM projects. Geographically, Morocco and South Africa are countries located in the far North and far South of the African continent respectively. The CDM permits developed countries to invest in projects that reduce green house gases (GHGs) in developing countries and earn carbon credits or carbon offsets Nhamo [2]. The Kyoto Protocol, which entered into force in February 2005, compels developed countries to reduce collectively GHGs by an average of $5.2 \%$ between the period 2008-2012 based on the 1990 levels United Nations [3].

\section{Generic CDM project cycle}

There is a series of steps that are involved in CDM project cycle. The key ones include (a) the preparation of the Project Design Document (PDD), (b) Validation and Approval, (c) Registration, (d) Monitoring, (e) Verification and Certification, and (f) Certification and Issuance of the Certified Emission Reductions - CERs). Details concerning these and other stages are presented in table 1 .

It is from the above generic CDM project cycle that host countries are given the jurisdiction to develop their own and similar CDM approval and evaluation criteria. The Kyoto Protocol (KP) requires that each host country designate a national authority for the CDM [4]. The Designated National Authority (DNA) as it is known is the legal entity or institution designated by the host country to manage the CDM project implementation processes. Given that one of the Protocol's two key goals is to assist developing countries that host CDM projects to achieve sustainable development, a key and early function of the DNA is to develop 'sustainability criteria' that will be used by the DNA to judge whether a proposed CDM project will contribute to the sustainable development of the country. If such a finding is made, then the project should receive the approval of the host country. This approval is a prerequisite for a CDM project and a factor that investors consider, often waiting for the DNA to indicate its support for a project before deciding whether to invest in it or not.

\section{CDM national structures}

The CDM project approval and evaluation criteria for Morocco is laid out in the 2004 CDM Strategy, Organisation and Procedures document Ministry of Landuse Management, Water and the Environment [5]. Morocco ratified the KP in September 2002 [5] and South Africa did likewise two months earlier in July 2002 Mqadi et al [6]. The Ministry of Land-use Management has been assigned as the DNA for CDM. In terms of the requirement that CDM projects must fulfil sustainable development requirements, Morocco has prioritised six key CDM 
project areas with promising potential for improving socio-economic and environmental situations namely: renewable energy development; energy efficiency development; better organised transport system resulting in higher energy performance and lower pollution impacts; healthier waste management; as well as forestation and reforestation.

Table 1: $\quad$ Generic stages in CDM project cycle.

\begin{tabular}{|c|c|c|}
\hline Stage & Description & Responsibility \\
\hline $\begin{array}{l}\text { Host country } \\
\text { approval }\end{array}$ & $\begin{array}{l}\text { Approval at the national level by the Designated } \\
\text { National Authority (DNA), consistent with } \\
\text { domestic laws and political priorities. }\end{array}$ & Project developer \\
\hline $\begin{array}{l}\text { Project Design } \\
\text { Document }\end{array}$ & $\begin{array}{l}\text { Identification of a concept and development of the } \\
\text { project design documents such as baseline } \\
\text { estimate, additionality, sustainable development } \\
\text { contributions, monitoring and verification plan and } \\
\text { stakeholders' opinion. }\end{array}$ & $\begin{array}{l}\text { Project developer or } \\
\text { participants }\end{array}$ \\
\hline $\begin{array}{l}\text { Validation and } \\
\text { Approval }\end{array}$ & $\begin{array}{l}\text { Third party validation of baselines and other } \\
\text { details to confirm that CERs as claimed by the } \\
\text { project are considered realistic. } \\
\text { Approval is when the DNA of each party involved } \\
\text { confirm their voluntary participation and the DNA } \\
\text { of the host country attest that such CDM project } \\
\text { contributes to the sustainable development of the } \\
\text { country }\end{array}$ & $\begin{array}{l}\text { Designated Operation } \\
\text { Entity (DOE) } \\
\text { Designated National } \\
\text { Authority }\end{array}$ \\
\hline Registration & $\begin{array}{l}\text { Registration of the project activity with the CDM } \\
\text { Executive Board, once the project has received } \\
\text { host country approval. }\end{array}$ & $\begin{array}{l}\text { CDM Executive } \\
\text { Board on demand of } \\
\text { DOE }\end{array}$ \\
\hline Financing & $\begin{array}{l}\text { Investor providing capital in the form of debt or } \\
\text { equity; investors may/ may not be carbon buyers. }\end{array}$ & Project developer \\
\hline Implementation & Building, commissioning and initiating operations. & Project developer \\
\hline Monitoring & $\begin{array}{l}\text { During commissioning and further operations, the } \\
\text { progress and GHG offsets are to be monitored. }\end{array}$ & Project developer \\
\hline Verification & $\begin{array}{l}\text { Independent assessment of project performance } \\
\text { against the validated design. }\end{array}$ & DOE \\
\hline $\begin{array}{l}\text { Certification and } \\
\text { issuance of CERs }\end{array}$ & $\begin{array}{l}\text { Based on the verification report, the CDM } \\
\text { Executive Board certifies and issues CERs. }\end{array}$ & Executive Board \\
\hline
\end{tabular}

[Source: Lee et al [4]]

For South Africa, national CDM structures are documented in the Regulations for the Establishment of a DNA for the CDM of 22 July 2005 Republic of South Africa [7]. From the Regulations, the Director-General of the national Department of Minerals and Energy has been designated as the DNA and according to Article 2(2) of the regulations shall perform all powers and duties of the DNA. This includes delegating any such power to execute the DNA's duties. What is of interest here is that the DNA does not stand out as a separate new authority but is integral to the day to day duties of the Director-General. This is a similar orientation to that of Morocco. In consultation with the Steering Committee, the DNA shall: (a) establish and apply a CDM project approval procedure, (b) evaluate CDM projects, (c) issue letters of approval, (d) facilitate effective participation by key stakeholders in the approval process of CDM projects, (e) promote CDM projects in the country, (f) monitor and report to the Minister of Minerals and Energy CDM activities and (g) deal with all donations 
for CDM as per the requirements of the Public Finance Management Act of 1999. Details regarding CDM project implementation national structures and procedures for both countries are summarised in table 2 .

Table 2: $\quad$ National structures and procedures for CDM.

\begin{tabular}{|c|c|c|}
\hline Attribute & Morocco & South Africa \\
\hline Institutions & $\begin{array}{l}\text { CDM DNA - encompassing } \\
\text { the CDM National Council } \\
\text { and Permanent Secretariat of } \\
\text { the CDM National Council }\end{array}$ & $\begin{array}{l}\text { DNA for CDM - encompassing the } \\
\text { Director General for the Department of } \\
\text { Minerals and Energy, Steering Committee } \\
\text { (SC) for the DNA and Expert Advisory } \\
\text { Committee. }\end{array}$ \\
\hline $\begin{array}{l}\text { Capacity } \\
\text { building }\end{array}$ & $\begin{array}{l}\text { Done to economic operators } \\
\text { and the CDM National } \\
\text { Council }\end{array}$ & $\begin{array}{l}\text { Done to key stakeholders at National and } \\
\text { Provincial scales }\end{array}$ \\
\hline $\begin{array}{l}\text { Internationally } \\
\text { promoting of } \\
\text { CDM in } \\
\text { Morocco }\end{array}$ & $\begin{array}{l}\text { Contact with potential CDM } \\
\text { investors, carbon buying } \\
\text { organisations and Annex I } \\
\text { Parties; Website created at: } \\
\text { www.mdpmaroc.com }\end{array}$ & $\begin{array}{l}\text { DNA specifies one of its key mandates as } \\
\text { promoting South Africa as a suitable and } \\
\text { attractive investment opportunity for } \\
\text { CDM project developers and overseas } \\
\text { investors; Special website established at: } \\
\text { http://www.dme.gov.za/dna/index.stm }\end{array}$ \\
\hline $\begin{array}{l}\text { Monitoring } \\
\text { international } \\
\text { CDM } \\
\text { negotiations }\end{array}$ & $\begin{array}{l}\text { Follow-up activities with the } \\
\text { CDM Executive Board and } \\
\text { discuss these during KP } \\
\text { Conference of Parties; } \\
\text { Follow-up on international } \\
\text { publications on CDM projects }\end{array}$ & Not clearly spelt out \\
\hline $\begin{array}{l}\text { CDM National } \\
\text { Council/Steering } \\
\text { Committee }\end{array}$ & $\begin{array}{l}\text { CDM National Council } \\
\text { comprises the President of } \\
\text { National Council and } 20 \text { high } \\
\text { level representatives including } \\
\text { those from } 10 \text { ministries }\end{array}$ & $\begin{array}{l}\text { Steering Committee comprised of a Chair } \\
\text { from the DNA and } 9 \text { national departments }\end{array}$ \\
\hline
\end{tabular}

The main difference between the two countries is that Morocco has more formalised procedures, especially regarding international promotions, lobbying and monitoring for CDM investment. The procedures also include a wider range of stakeholders in the CDM National Council compared to South Africa's Steering Committee that holds the same functions. However, the CDM National Council and the Steering Committee have similar roles, particularly those pertaining to the review and assessment of projects submitted for CDM to respective DNAs, development and approval of sustainable development criteria, Ministry of Land-use Management, Water and Environment; Republic of South Africa [5,7]. In addition, both these institutes were established in 2004.

\section{CDM project evaluation and approval procedures}

Morocco starts by acknowledging that one of the criteria that attracts a country to invest in CDM is the functioning of their DNA. Hence the more project endorsement process is clear, transparent and quick, the more investors will be prepared to initiate CDM projects Ministry of Land-use Management, Water and Environment [5]. The evaluation and approval criteria for both countries are similar in many respects (table 3 ) although Morocco appears to have much more streamlined procedures. 
Table 3: $\quad$ CDM project evaluation and approval procedures.

\begin{tabular}{|c|c|c|}
\hline Attribute & Morocco & South Africa \\
\hline $\begin{array}{l}\text { Preliminary } \\
\text { evaluation }\end{array}$ & $\begin{array}{l}\text { CDM Morocco Project Idea } \\
\text { Note (PIN) submitted - to } \\
\text { check whether it leads to real } \\
\text { and measurable GHG } \\
\text { reductions; conforms to the } \\
\text { national sustainable } \\
\text { development criteria; and has } \\
\text { no external negative effects. } \\
\text { All this takes a maximum of } \\
14 \text { days. }\end{array}$ & $\begin{array}{l}\text { Initial (voluntary) screening done with } \\
\text { developer submitting the Project Identification } \\
\text { (PIN) and application form that is reviewed } \\
\text { resulting in (a) a Letter of No-Objection } \\
\text { (leading to final submission) or (b) Letter of } \\
\text { Objection and comments leading to a complete } \\
\text { rejection or the revision of PIN and ultimate } \\
\text { final submission. All this takes } 30 \text { days. }\end{array}$ \\
\hline $\begin{array}{l}\text { In-depth } \\
\text { evaluation }\end{array}$ & $\begin{array}{l}\text { In-depth review of data and } \\
\text { project components with } \\
\text { regard to set international and } \\
\text { national sustainable } \\
\text { development criteria. Project } \\
\text { Design Document (PDD) } \\
\text { submitted by the promoter. } \\
\text { EIA required as per the } \\
\text { national regulations. All this } \\
\text { takes a maximum of } 28 \text { days. }\end{array}$ & $\begin{array}{l}\text { Developer submits PDD (inclusive of EIA) to } \\
\text { the DNA. PDD made available online for } \\
\text { public comments for } 30 \text { days whilst it } \\
\text { simultaneously undergoes review by the DNA. } \\
\text { Decision made by the DNA to either approve } \\
\text { (leading to the issuance of the Letter of } \\
\text { Approval) or reject (with reasons) leaving the } \\
\text { developer with an option to appeal to the } \\
\text { Minister of Minerals and Energy. Appeal to be } \\
\text { made within } 60 \text { days, the same amount of time } \\
\text { it takes to have a decision made on the } \\
\text { submitted PDD. Overall, either a } 60 \text { or } 90 \text { days } \\
\text { CDM project approval process is in place. }\end{array}$ \\
\hline $\begin{array}{l}\text { Sustainable } \\
\text { development } \\
\text { criteria }\end{array}$ & $\begin{array}{l}\text { CDM projects must contribute } \\
\text { to: the mitigation of global } \\
\text { carbon cycle; sustainability of } \\
\text { the local environment; creation } \\
\text { of employment; durability of } \\
\text { payments; macro-economic } \\
\text { plan; effect on costs; } \\
\text { technology autonomy and } \\
\text { sustainable use of natural } \\
\text { resources. }\end{array}$ & $\begin{array}{l}\text { Three broad criteria set: environmental } \\
\text { (covering aspects relating to impact on local } \\
\text { environmental quality; change in usage of } \\
\text { natural resources; and impacts on biodiversity } \\
\text { and ecosystems); economic (covering aspects } \\
\text { relating to economic impact and appropriate } \\
\text { technology transfer); and social (covering } \\
\text { aspects related to alignment with national, } \\
\text { provincial and local development priorities; } \\
\text { and social equity and poverty alleviation). In } \\
\text { addition, there is a general criterion that looks } \\
\text { at whether the distribution of CDM project } \\
\text { benefits are reasonable and fair. }\end{array}$ \\
\hline $\begin{array}{l}\text { Small scale } \\
\text { projects }\end{array}$ & $\begin{array}{l}\text { Defines thresholds for } \\
\text { renewable energy CDM } \\
\text { projects with a maximum } \\
\text { output capacity equivalent of } \\
\text { up to } 15 \mathrm{MW} \text {; energy } \\
\text { efficiency improvement } \\
\text { projects which reduce energy } \\
\text { consumption on supply and/ or } \\
\text { demand side by up to the } \\
\text { equivalent of } 15 \\
\text { gigawattshours per year; and } \\
\text { other projects that both reduce } \\
\text { anthropogenic emissions by } \\
\text { sources and that directly emit } \\
\text { less than } 15 \text { kilotones of } \\
\text { carbon dioxide equivalent } \\
\text { annually. }\end{array}$ & Not defined. \\
\hline
\end{tabular}




\section{CDM projects implemented: situation on the ground}

As of July 2006, Morocco had 60 CDM project proposal at various stages of approval Ministry of Land-use Management, Water and Environment [8] whilst South Africa had a third of this at 20 Department of Minerals and Energy [9]. Of the $60 \mathrm{CDM}$ projects for Morocco, three were registered with three others undergoing validation. South Africa on the other hand had two projects registered, none under validation and four with their PDDs approved by the DNA. Current Morocco's CDM projects have a potential of reducing 7 million tonnes of $\mathrm{CO}_{2} \mathrm{e}$ annually and South Africa's can reduce about 9.5 million tonnes. Details regarding CDM projects status for both countries as of July 2006 are presented in figure 1 .

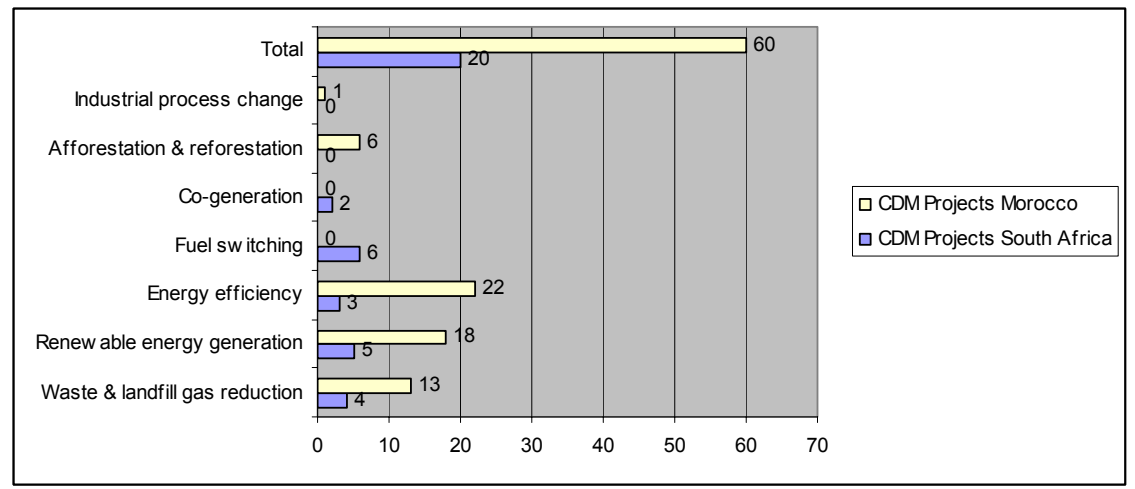

Figure 1: CDM project status as of July $2006(n=60$ for Morocco; $n=20$ for South Africa).

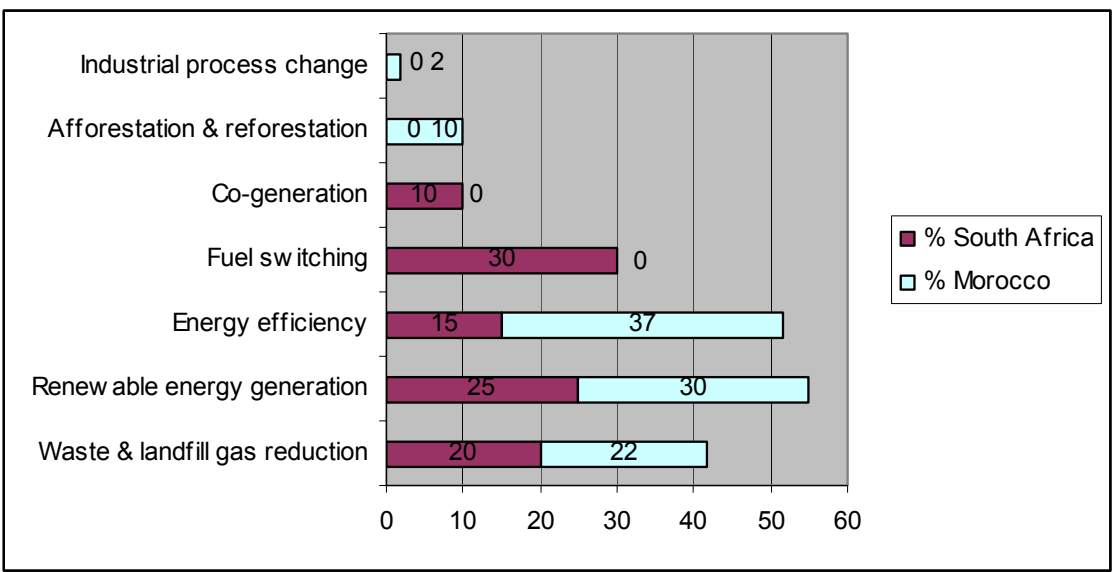

Figure 2: Sectoral distribution of CDM projects $(n=60$ for Morocco; $n=20$ for South Africa). 
There are contrasting insights in terms of sectoral percentage distribution of CDM projects in the two countries (figure 2). Energy efficiency account for 37\% in Morocco compared to South Africa's 15\%. Similarly, there are no fuel switching and cogeneration CDM projects proposed for Morocco and these comprise $40 \%$ of South Africa's projects. Likewise, there are no industrial process change, afforestation and reforestation CDM projects in South Africa, whilst these constitute $12 \%$ for those in Morocco. Both the renewable energy; as well as waste and landfill gas CDM projects have fairly equal proportions in both countries. South Africa's DNA has recently prescribed thresholds for afforestation and reforestation CDM projects Department of Minerals and Energy [10]. The minimum values for forest thresholds are stipulated as: (a) a single minimum tree crown cover value of $30 \%$, (b) a single minimum land area value of 0.05 hectares, and (c) a single minimum tree height value of two metres.

A summary of approved CDM projects, those under validation, those with approved PDDs as well as their capacity in terms of CERs for both countries is presented in table 4 . In addition to CDM projects with status indicated above, there are 18 others whose PINs have been approved in Morocco and 13 in South Africa.

Table 4: $\quad$ Summary of approved CDM projects.

\begin{tabular}{|c|c|c|c|c|}
\hline \multirow{2}{*}{$\begin{array}{l}\text { CDM Project } \\
\text { Status }\end{array}$} & \multicolumn{2}{|l|}{ Morocco } & \multicolumn{2}{|l|}{ South Africa } \\
\hline & Project & $\begin{array}{c}\mathrm{CO}_{2} \mathrm{e} \\
\text { (tonnes) }\end{array}$ & Project & $\begin{array}{c}\mathrm{CO}_{2} \mathrm{e} \\
\text { (tonnes) }\end{array}$ \\
\hline Registered & $\begin{array}{l}60 \mathrm{MW} \text { wind farm } \\
\text { (Essaouira) } \\
\text { Photovoltaic kits to light } \\
\text { up rural households in } \\
\text { Morocco } \\
10 \mathrm{MW} \text { wind farm } \\
\text { (Tetouan) }\end{array}$ & $\begin{array}{r}150,000 \\
39,500 \\
28,600\end{array}$ & $\begin{array}{l}\text { Kuyasa Low-Cost Urban } \\
\text { Housing Energy Upgrade } \\
\text { Project } \\
\text { Lawley Fuel Switch Project }\end{array}$ & $\begin{array}{r}44,000 \\
21,683\end{array}$ \\
\hline $\begin{array}{c}\text { Under } \\
\text { Validation }\end{array}$ & $\begin{array}{l}\text { Introduction of Heat } \\
\text { Recovery System at Jorf } \\
\text { Lasfar's chemical plant } \\
\text { Biogas recovery and } \\
\text { flaring (Oulija landfill) } \\
10 \mathrm{MW} \text { Wind farm for } \\
\text { the Tan Tan desalination } \\
\text { plant }\end{array}$ & $\begin{array}{r}13,800 \\
17,200\end{array}$ & None & - \\
\hline $\begin{array}{c}\text { PDD } \\
\text { approved by } \\
\text { DNA }\end{array}$ & $\begin{array}{l}\text { Biogas recovery and } \\
\text { flaring (Rabat Akreuch } \\
\text { landfill) }\end{array}$ & 76,00 & $\begin{array}{l}\text { Rosslyn Brewery Fuel } \\
\text { Switching Project } \\
\text { Bethlehem Hydroelectricity } \\
\text { Project } \\
\text { PetroSA Biogas to Energy } \\
\text { Emfuleni Power Project }\end{array}$ & $\begin{array}{r}107,403 \\
25,737 \\
30,000 \\
763,960 \\
\end{array}$ \\
\hline & Total $\left(\mathrm{CO}_{2} \mathrm{e}\right)$ & 409,900 & Total $\left(\mathrm{CO}_{2} \mathrm{e}\right)$ & 992,783 \\
\hline
\end{tabular}




\section{Conclusion}

This paper critically reviewed the CDM approval and evaluation criteria for Morocco and South Africa. The aim was to establish possible future competition points in attracting CDM foreign direct investment in these and other developing nations. The paper revealed significant differences in approval time frames and sustainable development criteria. It emerged that it takes about 42 days in Morocco for proponents to get responses on their proposed CDM projects compared to 60 days (if initial voluntary screening is excluded) and 90 days (if initial voluntary screening is included) in South Africa. The sustainable development criteria too, appear to be much stringent for South Africa compared to that of Morocco. By the time of writing this paper, $60 \mathrm{CDM}$ project proposals had been submitted and were at various approval stages in Morocco compared to 20 in South Africa. Although the number of CDM project proposals submitted to the South African DNA is only a third of those for Morocco, their annual potential to reduce GHGs is much bigger. This stands at about 992,783 of $\mathrm{CO}_{2} \mathrm{e}$ for South Africa compared to about 409,900 of $\mathrm{CO}_{2}$ e for Morocco. These figures show that effectively South Africa's realised potential is twice as much compared to that of Morocco. There is also a great chance that more CDM projects will be attracted into the forest establishments following the determination of the forest threshold by the DNA.

\section{References}

[1] Ellis, J., Winkler, H., Corfee-Morlot, J. \& Gagnon-Lebrun, F., CDM: Taking stock and looking forward. Energy Policy, 35, pp. 15-28, 2007

[2] Nhamo, G., Why can't we clean up our own act? South African Labour Bulletin, 30(2), pp. 10-13, 2006.

[3] United Nations, The Marrakesh Accords and The Marrakesh Declaration, United Nation Secretariat: Marrakesh, pp. 20-21, 2001.

[4] Lee, C.A., Plourde, D.M. \& Bogner, J.E., Landfill gas recovery: South Africa's low handling fruit for carbon credits trading. In: Institute of Waste Management of Southern Africa, (Ed). WasteCon2004.Johannesburg: Institute of Waste Management of Southern Africa, pp. 52-60, 2004.

[5] Ministry of Land-use Management, Water and Environment. CDM in Morocco: Strategy, Organisation and Procedures. Agdal: Climate Change Unit, pp. 5-8, 2004.

[6] Mqadi, L., Winkler, H. \& Churie Kallhauge, A., South Africa beyond Kyoto, South-South-North/Energy Research Centre University of Cape Town/Swedish Energy Agency: Cape Town, pp. 2 4, 2004.

[7] Republic of South Africa. National Environmental Management Act, 1998 Regulations for the Establishment of a Designated National Authority for the Clean Development Mechanism, Government Printer: Cape Town, pp. 3-7, 2005. 
[8] Ministry of Land-use Management Water and Environment. Moroccan CDM Project Portfolio (July 2006). Agdal: Climate Change Unit, pp. 1-3, 2006.

[9] Department of Minerals and Energy. CDM Project Status. Pretoria: Government Printer, pp. 1-2, 2006.

[10] Department of Minerals and Energy. DNA Notice on Forest Threshold for CDM. Pretoria: Government Printer, pp. 1, 2006. 